\title{
PIGMENT PROFILE OF OLIVE OILS DETERMINED BY SCHOOL MEASUREMENT SYSTEM LABQUEST AND SPECTROMETER
}

\author{
Jana BRANIŠA, Zita JENISOVÁ, Klaudia JOMOVÁ
}

\begin{abstract}
Coloration of foods is a significant and important attribute for both producers and consumers, respectively. The following paper present using combination of digital technologies during practical laboratory exercises at secondary school alternatively at university. We decided to work with computer and Vernier LabQuest - standalone interface used to collect sensor data with its build-in graphing and analysis application. The school experiment is focused on introducing the chemistry of everyday life into chemistry education. Pigment spectra were measured by Vernier school measuring system with attached spectrophotometer. Obtained spectra of olive oil samples confirmed that oils contained mainly the following pigments: pheophytin a, pheophytin b, chlorophyll $\mathrm{a}$, chlorophyll $\mathrm{b}, \beta$-carotene and lutein. The focus was also put on thermal pigment degradation and acidity changes of olive oils commonly present during the food processing. The experiments were designed to enhance the research and academic value of school experiment.
\end{abstract}

Key words: LabQuest, spectrometer, olive oil, pigments.

Abstrakt: Dôležitým vizuálnym atribútom pri sledovaní kvality produktu pre spotrebitel’ov i výrobcov je farba potravín. Predkladaný príspevok predstavuje experiment zameraný na chémiu bežného života a je realizovaný s implementáciou digitálnych technológií, konkrétne školského meracieho systému Vernier s pripojením interface spektrofotometer. Experiment je adresovaný pre študentov prírodovedných predmetov stredných, resp. vysokých škôl. Ciel’om je zvyšovanie prírodovednej a matematickej klúčovej kompetencie, formou čítania a interpretovania grafických výstupov, pre vzorky olivových olejov obsahujúcich pigmenty, napr.: chlorofyl a, chlorofyl b, $\beta$-karotén a luteín a iné. Kvalitatívne merania sú realizované na vzorkách olejov, ktoré boli vystavené tepelnej degradácii a zmene pH. Návrh je realizovaný tak, aby sa zabezpečil rozvoj vyššie úrovne porozumenia a prírodovedného myslenia $u$ študentov.

Kl'účové slová: LabQuest, spektrometer, olivový olej, pigment.

\section{INTRODUCTION}

Current society is full of turbulent changes. We have converted from the industrial to the information society. The creation and manipulation with information is very important economic activity. Working with information is closely connected with using new technologies especially ICT. Nowadays digital literacy as ability to effectively and critically evaluate and create information using range of digital technologies is one of the crucial abilities. Every new educational technology is related to changes in the field of curriculum. Schools have to continuously update their educational materials to keep up with accelerating technological developments. Strategies for the implementation 
of ICT have to be closely connected with educational innovations.

Digitalization is the process of converting information to digital format. It makes information easier to preserve access and share (online or offline). Mentioned process will change the face of education.

In chemistry education the implementation of digital technologies we can divide into some main areas.

The first area is using computer graphics (f. e. animation which explaining chemical reaction synthesis, decomposition, single displacement, double displacement, combustion etc.). The second area is represented by molecular modelling which encompasses all theoretical methods used to model molecules. The last areas is using of real or visual chemical experiment. Using computer as a part of experimental activities we could create useful combination of data colleting, analysing, simulations and dataprocessing programs.

One of the main objectives in the field of preparation of future chemistry teachers is to implement digital technology into educational process within the first years of undergraduate study and carry on continuously in the graduate level of university study. Using digital technologies is integral part of curriculum (educational program) for future chemistry teachers at Constantine the Philosopher University in Nitra - Department of Chemistry.

Using computer-assisted science laboratories (Microcomputer based laboratory) has more than ten years of tradition in Slovak schools. At school in Slovakia there is more than ten years tradition of using computer-assisted science laboratories (Microcomputer based laboratories).
Using mentioned technologies supports cognitive development, active exploration and also developing key competences for lifelong learning which are necessary for personal fulfilment and development, social inclusion, active citizenship and employment (especially mathematic competence and basic competences in science and technology, digital competence). Mentioned laboratories strengthen analyzing and provide more opportunities for discussion of obtained data encourage the creation of logical connections to different situations and develop natural science literacy [1].

Experiments in the computer lab are built on the premise that the teacher plays a key role in introducing a new information and communication technologies into the classroom. Brestenská's research [2] showed that practicing teachers haven't felt prepared to work with the computer and usually have compared their skills with the skills of their students. Therefore, a number of quantitative experiments using a school computer assisted science laboratories have been included to the preparation of future chemistry teachers within the subject "Technology and methodology of educational experiments in chemistry" as a part of the chemistry of everyday life.

We prepared the special experimental procedures in order to possibility use modern technologies and new teaching strategies at the school classes. The main target was except development of basic competences in science and technology, digital competences also strengthen mathematic competence - using and reading graphs which visually represent the relationship of data. During experiment realisation it is necessary to implement modern educational strategies f.e. inquiry and experience 
teaching methods or in some case project education.

\subsection{Measuring system LabQuest - Vernier}

LabQuest is a standalone and computer interface for Vernier sensors. The newest model contain also touch screen to collect graph, and analyse data in classroom, laboratory or in the field, which could be very interesting for students. It is possible to use it as a separate device to collect data and to process them or it can be used as a computer interface unit with the ability to connect more than 70 sensors and other equipments (including thermometer, $\mathrm{pH}$ sensor, colorimeter, ethanol sensor, polarimeter, UVVIS spectrophotometer, stopwatch, scientific calculator, microphone and periodic table with detailed description of elements).

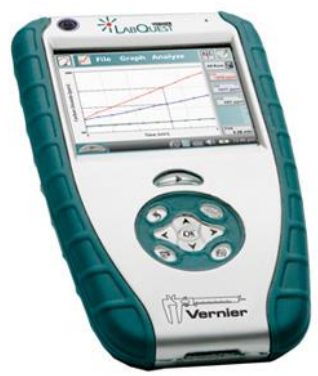

Fig 1: Interface LabQuest

(Source: www.vernier.com)

Data export into the computer is provided by software Logger Pro. In here the analysis, correction and calculations connected with charts, tables or their excerpts are available. It makes collecting data easier. The interface is very simple and it makes learning intuitive by making science visual

Using mentioned interface with computers could help students to develop mathematical competences and basic competences in science and technology f. e. using tables and graphs, developing techniques and other manipulative skills.
We proposed and realised chemical experiment using LabQuest interface focused on everyday life. We decided to use spectrometer which is not one of the favourite sensors.

\subsection{Experimental Task Using Computer Measuring Systems with Spectrometer}

It is very important to create and strengthen connections between chemistry education and everyday life. One of the main targets of modern education is to increase its efficiency. It is not possible without implementation modern digital technologies which are inseparable part of our lives. Computer and properly choosing experiment could make activities in laboratory simpler for students. Using spectrometer sensor students could make out chemical compounds according to shape of graph.

Good nutrition is strongly liked to education. This is reason why we decided to choose olive oil as target of our research activities. The positive effects of virgin olive oil re well-known not only among scientists studying it but also among laymen. A collocation "olive oil" can be frequently found in mass media as well as in scientific publications. It is mentioned mainly in connection with health and healthy diet. There are people who are truly convinced of its health-beneficial properties but some still hesitate. Nutrition experts advise virgin olive oil consumption because of its positive effects on human health (f.e prevention of atherosclerosis and other heart diseases, reduce breast cancer risk and protect against Alzheimer disease.)

\subsection{Characteristic of olive oils}

Virgin olive oil, an excellent natural food, is obtained from olive fruit (Olea europaea L.) by mechanical or physical procedures (such as milling, beating, centrifugation, and 
decantation). Its composition varies widely, depending on fruit variety, degree of fruit ripeness, environmental conditions, growing region, and techniques of processing and storage [3]. These factors influence oil colour, which is one of the basic quality characteristics of virgin olive oil. Olive oil colour is solely due to the solubilisation of pigments present in the original fruit. The product is best defined by a green-yellowish colour, although the green hue may vary depending on the variety and the predominant state of ripeness of the mixture of fruits used $[4,5]$.

\subsection{Pigments in olive oils}

The chlorophylls and carotenoids presence greatly influences the olive oils colour [6], which is a very important sensory parameter evaluated by consumers. Chlorophyll pigments are responsible for the greenish hues of virgin olive oil. Among chlorophylls, pheophytin a, is found in considerable amounts in olive oils. The major "yellow" pigments of virgin olive oils are lutein and $\beta$-carotene [7].

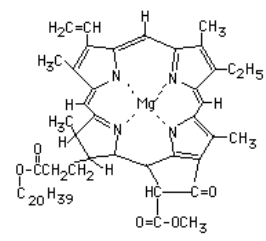

Chlorophyll a
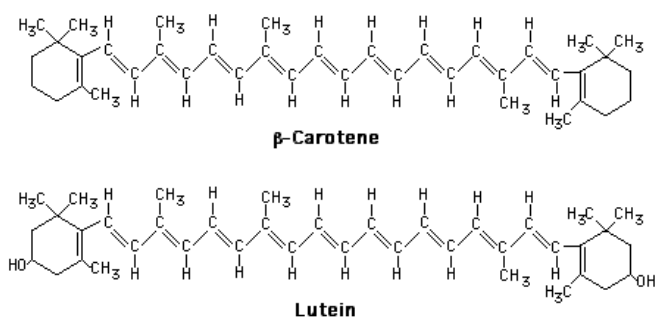

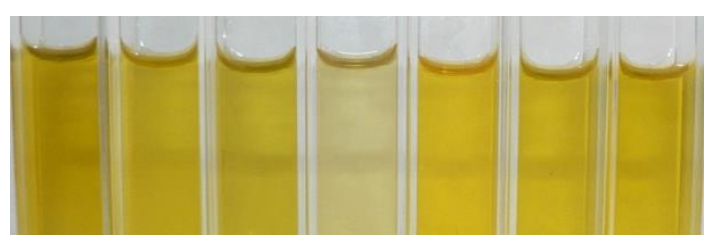

Fig 2: Chemical structures of pigments

(Source:

www.sci.sdsu.edu/class/bio202/TFrey/ChemRe v.Images/ChlorophyllCarotenoids.gif)

\subsubsection{Detection of olive oil pigments by spectrophotometer}

Until relatively recently, this quality attribute was evaluated by visual comparison with standard solutions, using an adaptation of the methods developed for oilseeds [8]. Currently, colorimeters are being introduced to automate this process [9]. Chlorophyll a has 2 main absorption maxima located at 430 and $664 \mathrm{~nm}$. In the case of pheophytin a, the 1st absorption maximum is located at a shorter wave length $(407 \mathrm{~nm})$, and the intensity of the $2 \mathrm{nd}$ one is reduced, although it is located at a similar wave length $(666 \mathrm{~nm})$. The major carotenoids in olive oils have their absorption maxima located at positions of 424,448 , and 476 in the case of lutein and 454 and $480 \mathrm{~nm}$ in the case of the carotene [10].

\section{Laboratory Methods and Data}

We used $10 \mathrm{~mm}$ cuvette for the measurement. The dilution of sample was not necessary for obtaining suitable results. The oil types used (producers mentioned below) were extra virgin olive oils (6) and one sample was labeled light olive oil.

\subsection{Procedure}

a) Prepare a blank by filling an empty cuvette $3 / 4$ full with distilled water.

b) Place the blank cuvette in the spectrometer and calibrate it. 
c) Obtain another cuvette and fill the cuvette $3 / 4$ full with the olive oil and place it in the spectrometer. Before inserting a cuvette into the spectrophotometer, wipe it clean and dry with a kimwipe, and make sure that the solution is free of bubbles. Do not touch the clear sides of the cuvette (Fig 3).

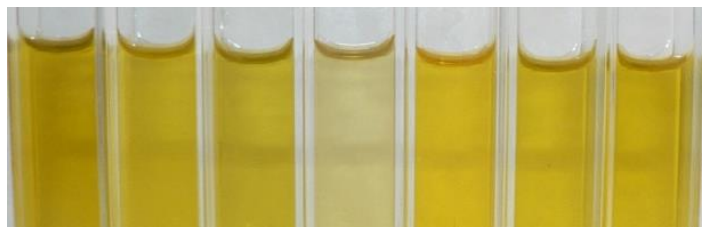

Fig 3: Samples of olive oil in cuvette

Carefully pour each oil sample into a clean 10 $\mathrm{mm}$ cuvette and observe for air bubbles or other anomalies. Make sure the cuvette sides have been cleanly and place it into the spectrometer.

Start the measurement and after a few seconds you will see full spectrum graph of the olive oil witch will be showing wavelengths of high and low absorbance.

Prepare ceramic crucibles and pour the olive oil samples into them. Heat the oven to $200{ }^{\circ} \mathrm{C}$ and heat ceramic crucibles with the oil samples for 20 minutes. When crucibles are sufficiently cooled down, measure the spectrum of oils.

Mix olive oil with an acid (vinegar, balsamic, lemon juice) in a ratio of $3: 1$. Allow 20 minutes to react and filter by suction the separated aqueous layer with a vacuum pipette. Measure the corresponding spectra afterwards. 


\section{Results}

Výzkumný článek

Complete list of used olive oils, countries of origin and bottle types for storage are summarized in Tab 1.

Tab 1: Samples of olive oils

\begin{tabular}{llll}
\hline & Oil Typ & Country of Origin & Colour of Bottle \\
\hline 1 & 100\% Extra virgin olive oil & Spain & Transparent glass bottle \\
2 & 100\% Extra virgin olive oil & Spain & Green glass bottle \\
3 & $100 \%$ Extra virgin olive oil & Croatia & Dark Green glass bottle \\
4 & $100 \%$ Light olive oil & Spain & Transparent PET bottle \\
5 & $99 \%$ Extra virgin olive oil with $1 \%$ & Italy & Transparent glass bottle \\
& lemon & & \\
6 & $100 \%$ Extra virgin olive oil & Spain & Green glass bottle \\
7 & $100 \%$ Extra virgin olive oil & Spain & Green glass bottle \\
\hline
\end{tabular}

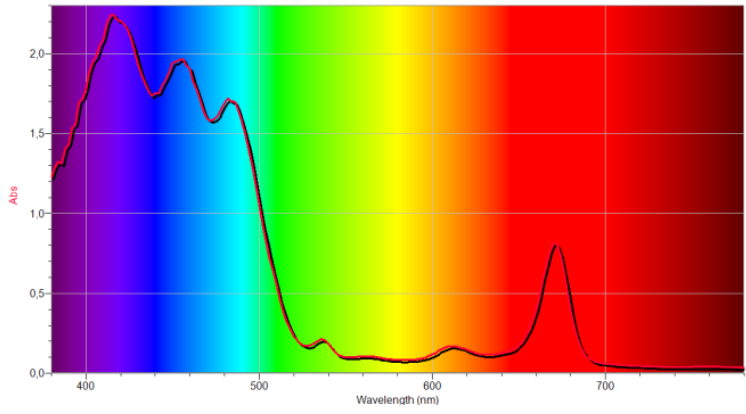

\section{Sample 1}

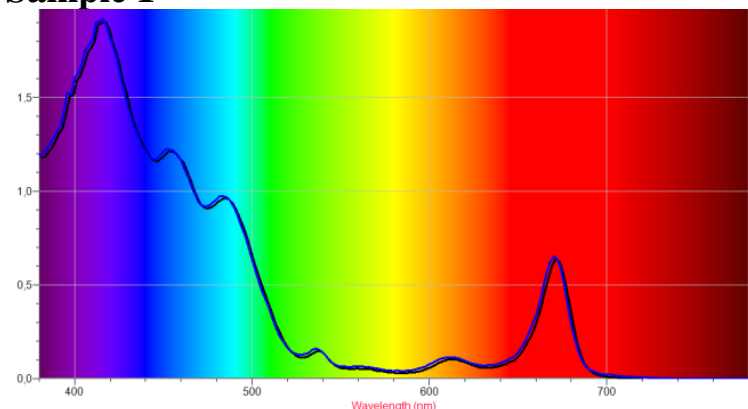

Sample 3

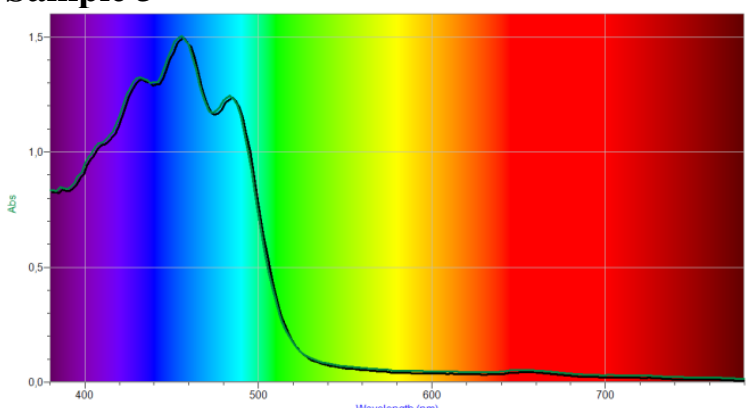

Sample 5

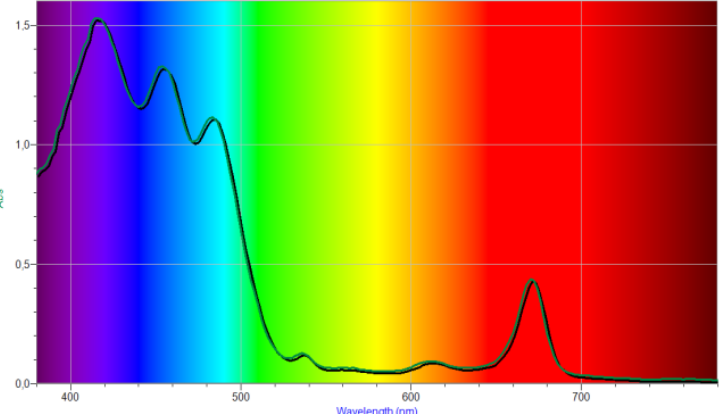

Sample 2

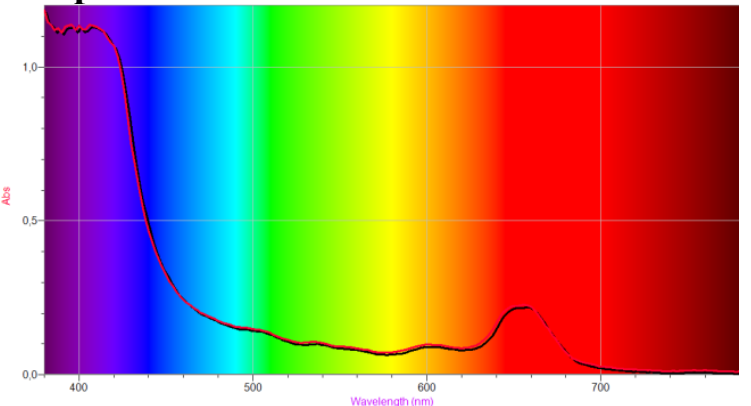

Sample 4

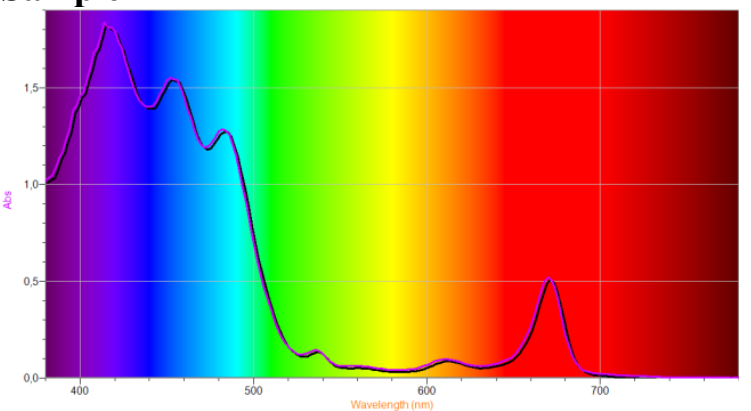

Sample 6 


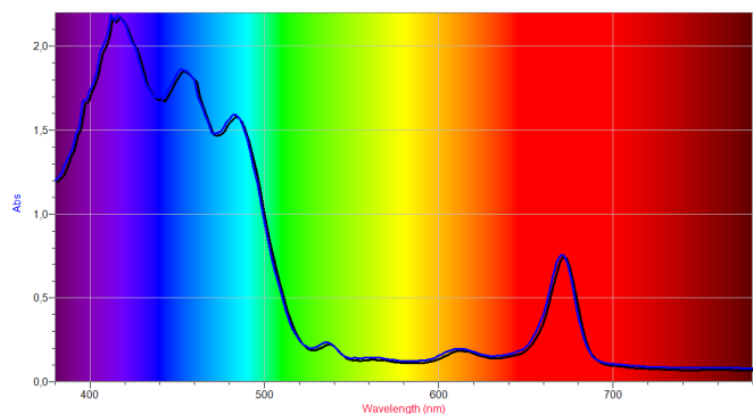

\section{Sample 7}

Fig 4: Visible spectra absorption (380 - $780 \mathrm{~nm})$ of olive oils

UV-VIS spectra were recorded in the range of wave length 380-780 $\mathrm{nm}$. In pictures above (Fig 4) of obtained spectral curves 7 regions of maximum absorption can be seen: 410 to $420 \mathrm{~nm}, 450$ to 455 nm, 480 to $485 \mathrm{~nm}, 530$ to $535 \mathrm{~nm}, 560$ to $565 \mathrm{~nm}$, 610 to $615 \mathrm{~nm}$, and 660 to $673 \mathrm{~nm}$. For clarity, the absorbance maxima were divided into three groups according to wave length (Tab 2).

Tab 2: Absorbance maxima of olive oils according to wavelength

\begin{tabular}{cccc}
\hline & & $\begin{array}{c}\text { Maximum wavelengh } \\
(\mathrm{nm})\end{array}$ \\
\hline & Purple- Blue & Green- Yellow & Orange-Red \\
1 & $416,456,482$ & $538^{*}, 612^{*}$ & 672 \\
2 & $416,454,482$ & $536^{*}, 612^{*}$ & 672 \\
3 & $416,454,484$ & $536^{*}, 612^{*}$ & 672 \\
4 & 392 & & $650^{*}$ \\
5 & $416,454,484$ & $565^{*}$ & 672 \\
6 & $414,454,484$ & $536^{*}, 612^{*}$ & 672 \\
7 & $416,454,484$ & $536^{*}, 612^{*}$ & 672 \\
\hline
\end{tabular}

*peak with low intensity

After the conclusion of the second part of the experiment, in which olive oils were heated, it was possible to determine visually, that there was a loss

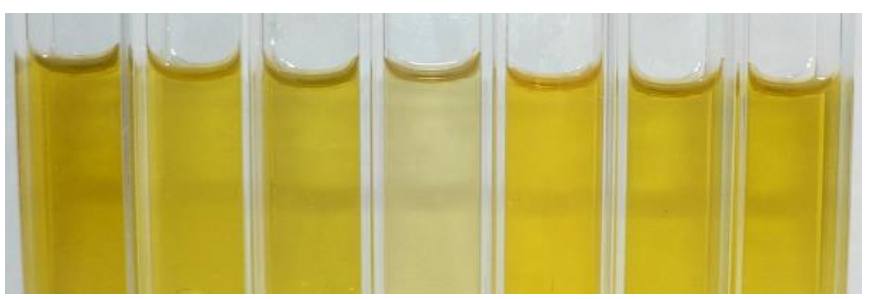

Fig 5: Samples of olive oil before heating $\left(200{ }^{\circ} \mathrm{C}\right)$ of pigment in samples of olive oils, because the typical yellow-green to greenish-gold coloration disappeared.

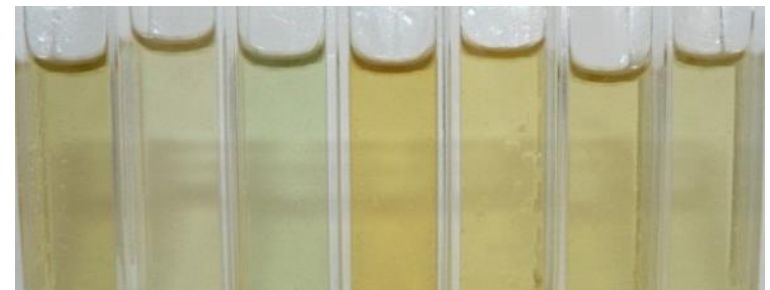

Fig 6: Samples of olive oil after heating 


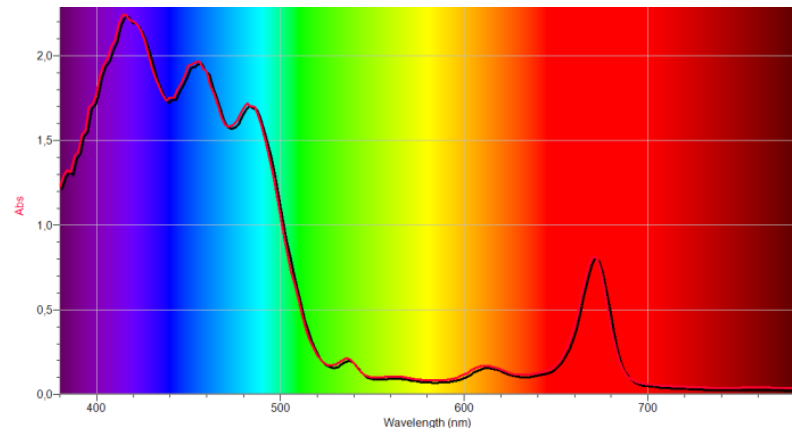

Sample 1 (before heating)

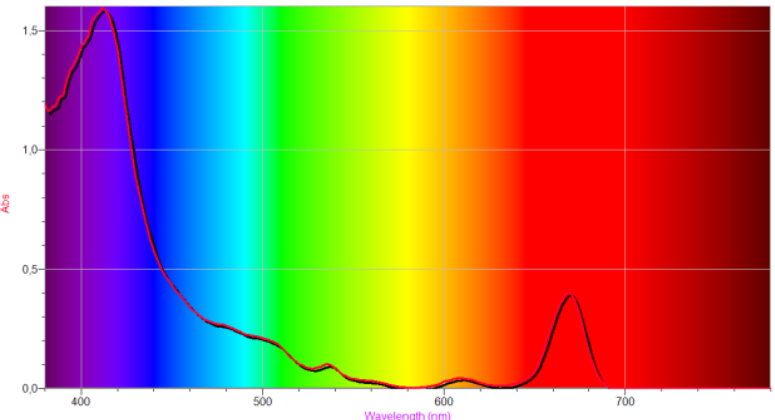

Sample 1 (after heating)

Fig 7: Absorption visible spectra (380- $780 \mathrm{~nm}$ ) of sample No.lolive oil.

Tab 3: Absorbance maxima of sample No.1 olive oil before and after heating

\begin{tabular}{llll}
\hline Samples No.1 & \multicolumn{3}{c}{ Maximum wavelength $(\mathrm{nm})$} \\
\hline & Purple- Blue & Green- Yellow & Orange-Red \\
$\mathrm{t}-25^{\circ} \mathrm{C}$ & $416,456,482$ & $538^{*}, 612^{*}$ & 672 \\
$\mathrm{t}-200^{\circ} \mathrm{C}$ & 410 & $535^{*}, 609^{*}$ & 670 \\
\hline
\end{tabular}

* peak with low intensity

From the measurement results (Tab 3), it is clear that, e.g.: chlorophyll a and chlorophyll b are mostly transformed into pheophytin by the substitution of magnesium ions in the porphin ring by hydrogen ions. Mentioned transformation of chlorophyll leads to a change from green colour oil to olive-yellow colour, which can be perceived by consumers as a quality loss.

After mixing of olive oil with balsamic vinegar respective spectra for all oil samples were measured again. There were no significant changes visible in spectral profiles in this case.
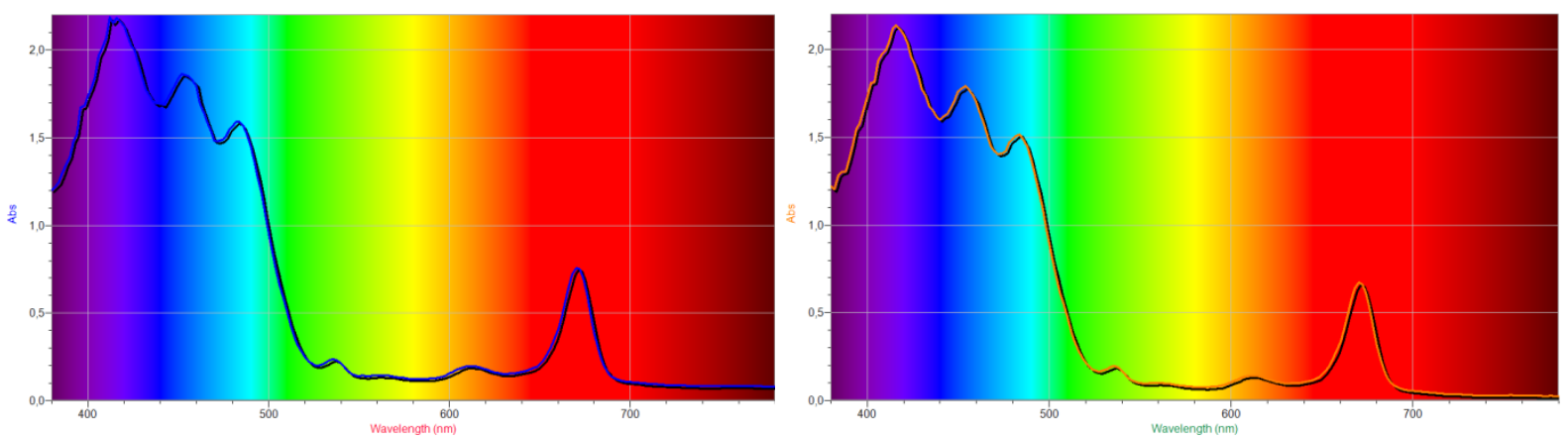

Sample 7 (before adding acid)

Sample 7 (after adding acid)

Fig 8: Absorption visible spectra (380- $780 \mathrm{~nm})$ of sample No.7olive oil. 


\section{Discussion}

It can be concluded that main components in used olive oils samples were: pheophytin $a$, pheophytin $b$, chlorophyll a, chlorophyll $b, \beta$ carotene and lutein. It is evident that all of samples except for sample 3 had their absorption maxima in conformity with values mentioned above. It can be predicted that the sample contained oil produced from olives of poor quality or it was made from cheap oils colored by additional pigments. The event simulation (use of olive oil for frying) led to the formation of a large number of degradation products. The process of degradation of pigments is not simple, but proceeds in several elementary and competitive steps, which result in configuration structural changes (isomerization of reaction) and subsequent degradation to colorless products. After mixing olive oil with balsamic vinegar, no change in the spectrum of any sample oil has been observed. However, in case of Sample No. 5 , which besides olive oil contained $1 \%$ of lemon juice, it is clearly visible from the measured spectrum that absorbance in the range of the chlorophyll pigments $(660-680 \mathrm{~nm})$ is much lower than in other oil samples. From the analysis of obtained data it is evident that a longer exposure to acids (balsamic vinegar, lemon juice) has impact on the concentration of pigments and may cause their degradation, as can be seen in the aforementioned Sample No. 5.

\section{Conclusion}

UV-VIS spectroscopy is a valuable method for pigment detection present pigments in food, drinks, etc...

We would like to present that it is possible to realize mentioned experiment at school laboratory using simple digital technologies. By exploratory experimentation the students are driven to the fact that chemistry is an important part of everyday life. This fact leads to the assumption that presented experiments have a high motivational value. We realized experiment with future chemistry teachers. We could state that it was interesting for them. They worked intently and their results were correct.

Concurrently we realized informal interview focused on using LabQuest interface. All our students were very enthusiastic and propose other experiments for measurements (pigments in tree letters in autumn, pigments in food, etc.) Mentioned experiments it is possible to realize at laboratory works on $3^{\text {th }}$ grade at secondary schools (Theme: Chemistry in everyday life: Pigments: Lipids, etc.). It is necessary to use computers for experiments and inquiry during process of education future science teachers.

\section{References}

[1] ZELENICKÝ, L. - VALOVIČOVÁ, L. JENISOVÁ, Z. - ŠTUBŇA M. Počitačom podporované experimenty. Nitra: FPV (2011), p.150. ISBN 978-80-8094-906-8

[2] BRESTENSKÁ, B. and NAGY, T. Implementácia IKT do vyučovania chémie na ZŠ a Š́. Bratislava: ŠPÚ (2001), p. 123. ISBN 80223-1943-0

[3] BARRANCO, D. - FERNÁNDEZESCOLAR, R. - RALLO, L. El Cultivo del Olivo. Junta de Andalucia, Consejería de Agricultura y Pesca and Ediciones Mundiprensa, Madrid, Barcelona, México(1996).

[4] MÍNGUEZ-MOSQUERA, M.I et al. Pigments Present in Virgin Olive Oil. Journal of the American Oil Chemists' Society. 67 (1990) 192-196.

[5] MÍNGUEZ-MOSQUERA, M.I. et al. Color-Pigment Correlation in Virgin Olive Oil. Journal of the American Oil Chemists' Society. 69 (1991) 332-336.

[6] MOYANO, M.J. - HEREDIA, F.J. MELENDEZ-MARTINEZ, A.J. The Color of Olive Oils: The Pigments and Their Likely Health Benefits and Visual and Instrumental Methods of Analysis. Comprehensive. Reviews in Food Science and Food Safety. Volume 9, Issue 3 (2010) 278-291.

[7] GIUFFRIDA, D. - SALVO, F. SALVO, A. - PERA, L. - DUGO, G. Pigments composition in monovarietal virgin olive oils from various sicilian olive varieties. Food Chemistry, 101 (2007) 833-837.

[8] GUTIERREZ, G. - QUIJANO, R. GUTIERREZ-ROSALES, F. Rapid Method to Define and Classify the Color of Virgin Olive Oil, Grasas Aceites 37 (1986) 282-284.

[9] WAN, P.J. - HURLEY, T.W. - GUY, J.D. - BERNER, D.L. Comparison of Visual and Automated Colorimeters-An International Collaborative Study, Journal of the American Oil Chemists' Society.75 (1997) 731-738.

[10] MOYANO, M.J. - HEREDIA, F.J. MELENDEZ-MARTINEZ, A.J. The Color of Olive Oils: The Pigments and Their Likely Health Benefits and Visual and Instrumental Methods of Analysis. Comprehensive Reviews in 
Food Science and Food Safety. Volume 9, Issue 3 (2010) 278-291.

Mgr. Jana Braniša, PhD.

Katedra chémie

Fakulta prírodných vied UKF
Trieda Andreja Hlinku 1

94974 Nitra, SR

Tel: + 421-37-6408659

E-mail: jbranisa@ukf.sk

Www pracoviště: www.kch.fpv.ukf.sk 